\title{
Rational Analysis of the Power and Role between Teachers and Students
}

\author{
Fang Li \\ BOWEN middle school of Feixian \\ Feixian, Shandong, P.R. China
}

\begin{abstract}
The evident disparity in power and status between teachers and students is concretely showed in the interpersonal interactions between them during class. We need to find out the optimum cut in point between power control and equal cooperation. To seek the cooperation and equality between teachers and students are more to make the class teaching much more effective than weaken teachers' authority. Only by solving the factors that affect the power and status of teachers and students in the teaching process, can we achieve the best teaching effect by solving the root causes of conflict and rationalize the relationship between teachers and students.
\end{abstract}

Keywords—power between teachers and students; role; conflict; cooperation; status

\section{INTRODUCTION}

According to Webber, power means that the actor in certain social relationship enforce his (or her) own will forcibly, while regardless of the objections and the consequence of his (or her) behavior. As can be seen from the definition, the power is centralized in individual, and one can impose his own will on others, which reflects the asymmetry in power relations. Power has bipolarity, which involves the active one (people in power) and the passive one. The formation of power requires two conditions, namely, motive and resource. The two are interrelated and motivated; in the absence of motivation, the resources will be reduced; in the absence of resources, the motivation will be futile. The absence of either will lead to the collapse of power.

According to Webber's theory of power, we can draw some conclusions from the historical tradition of China, in the feudal society of China, a firm and solid class concept and system were established. Some people on the upper level have the supreme power, which is to satisfy the two conditions of Webber's theory of power: motivation and resources. In the social environment, the generation of power has a large amount of resources. Furthermore, the bondage of traditional ideas provides sufficient motivation for the generation of power.

\section{THE RESOURCE OF TEACHERS’ POWER}

Institutional resource is the first resource for teachers' power. It is generally believed that "leadership origins from external organizations and systems instead of from relations with other members" [1]. Teachers' power in practice is derived from rights. The legal rights of teacher are the institutional resource of teacher's power. According to the seventh, article of Teacher's Law, among the rights vested with teachers, two of which are about students (the rest are omitted): the first, carry on education and teaching activity, and develop teaching reform and experiment. the second, instruct students on studying and developing.

As can be seen from rights vested with teachers, relative to rich and diverse class life, these two rules are excessively general, and certainly provide conditions for the generation of teacher's power. Just for the good object--- passing on knowledge to students, teachers will take bad means, and will not care about the possible consequence they may lead to, they tend to ignore the other legal items. According to the fifteen article of The Law of the Protection of Juveniles, teaching staff in school and kindergarten must respect human dignity of juveniles, and shall not impose corporal punishment, corporal punishment in disguised form, or any other behaviors that will insult human dignity on juvenile students and children.

Public recognition of traditional teacher-student relationship model is the second external resource of teacher's power [2]. There are many excellent things in traditional culture, and in such a long feudal society, oppression of human stable cultural traditions also formed. This cultural tradition regards one-sided obedience as the first principle, and social values are only the controlling function of education. For a long time, the society expect teachers to regard the father-son relation as consult frame when they deal with teacher-student relation (so called "as a teacher, as a father"), and ask teachers to control students strictly, while students should obey their teacher absolutely. Among the whole teaching process, teaching is the major concern while students' studying is ignored; the passing of knowledge is valued while nonintelligence factors in students' study is ignored, and so forth. In the class, what teacher expects is that students can answer their questions according to lesson plan; the task of them is to lead students to get the predetermined answer. Actually, students are acting the role of coordinating teachers to finish the teaching plan during the teaching. Such traditional teaching conception and teacher-student relation model have deeply rooted influence on teacher and students, and meanwhile they are recognized by a considerable part of people in society, which also becomes another external resource of teacher's power.

More than that, students' parents even hand their own power to teachers, so as to fulfill the aim of promoting social 
status of students through education, thus strengthen teacher's awareness of" controlling" students[3].

Because of this, we believe that this power is a so-called traditional power, which based on the legitimacy of the old, traditional, inviolable, and the status of the person performing the power. The students, parents, and teachers who are affected by traditional ideas and concepts give teachers more power, which is not a completely rational power, is not a purely personal worship, more is because the binding of an idea. China in ancient times on the status of teachers particularly admired, thus leaving a proverb: a teacher for a day is a father for a lifetime.

\section{FACTORS THAT RESTRICT INFLUENCE OF TEACHER'S POWER}

Teacher's power mainly determined by two factors: teacher himself (or herself) and students themselves Factors of teacher himself (or herself) involve following aspects:

\section{A. Knowledge}

Teacher masters knowledge---- resources that is very important for students, thus it enable teacher has power outside of legal rights. "In most societies, traditionally speaking, parents has unlimited power in punishing their children. And teacher, being agent of such society, has same power as well." Even if teacher violates students' legal rights when he (or she) exercise this power, but because of the student's own ideas, the teacher has the right to corporal punishment or other punishment, students will not resist definitely or strongly. However, such power is exactly the power other people (except parents and other family) do not have, and it makes the privilege of teacher.

For students, teacher is the embodiment of knowledge, thus teacher has power entrusted by knowledge. Knowledge, being the product of understanding world, can in turn become the tool with which people changing the world, and is meaningful to individuals of society. While all of these are prerequisites that makes knowledge give people power. If cognitive ability of elementary students is far below this, for them, the most direct aim of learning knowledge possibly be getting placement winning praise, changing life situation. So they need to empower themselves with power, even though students are studying the knowledge passed on from teacher totally out of passive attitude. After all, studying is the task students should have finished.

Besides, in class, every student has his (or her) own interest or hobby, and will inevitably prefer the teacher which teaching the subject they are interested in, such affinity will help to enhance the influence of teacher's power. When a student's subjective love a teacher, this is out of the traditional power category, turned into a kind of personal subjective emotional behavior, the teacher in the student heart status significantly improved this power with a certain color of personality cult.

\section{B. Personality}

In practice, different teacher has different influence in power. As for elementary school teachers, theoretically speaking, such difference is more determined by the personality factor of teacher himself (or herself) than by his (or her) knowledge storage. Because of the age of the students, their knowledge of a lot of things just stay in some appearances, a strong affinity of the teachers tend to be more than a lot of knowledge of the teacher is more likely to approach them. Personality is a complex of many factors, and shows on how you treat other people, do with matter and treat yourself, such as organizational capacity, language expression ability, determination and fortitude and so on, all of these will strengthen or weaken the influence of teacher's power. Besides, age is another factor that will influence of teacher's power. Because of the age gap between teacher and student, the young should respect the seniority, which gives teacher corresponding mental advantage during the process of teacher-student interaction, and such advantage plays active role in playing teacher's power.

\section{The way teachers play their power}

Increasing amount of knowledge and traditions have been passed on to students from teachers for thousands of years, therefore, along with such situation, academic, authoritative, strict discipline come into birth, it reflects that the society itself is built on strict and authoritative principles. Thus, it set example of authoritative teacher-student relation, and such example is still popular in most of universities around the world. For teachers, the way in which power is exercised is passive or proactive. For active way, the traditional approach is recognition, appraise and compliment. The praise from teachers is much more tempting than praise from parents, from their pioneers or the elders. For students stepping into elementary school, the studying activities has much more value on themselves, and the competition behavior is much more intense, while such competitive atmosphere adds to the charm of teacher's praise, and meanwhile will strengthen teacher's motive to play their praise power. However, in practice, teachers play a passive way, very few praise students.

Reward and punishment are the powers of teacher. Even though the Teacher's Law has stipulated explicitly that, the theorists and educational administrations do not encourage and even oppose corporal punishment upon students, but, because that teachers have power of "carrying on teaching activity", so they have the power of rewarding or punishing students[4]. Therefore, punishing students is a common phenomenon in educational practices. According to observations, the rate of teachers playing their power in passive way is higher than that in active way. It ranges from details like changes in language rhythm or facial expressions to specific criticism, abuse or corporal punishment. When playing their power of punishment, facing students that has made same mistakes, teachers tend to give more strict punishment to students that has bad daily performance, while give students that has good daily performance only mild punishment or warning, or even impunity. As can be seen from this, the sense of unfairness resulted from reward-punish way of teachers will weaken the influence of teacher's power.

\section{Teaching strategy}

Teaching is the basic power of teachers, the other powers are generated around teaching. 
When teachers exercise their power, teaching strategy (teaching method) will undoubtedly become the major factor that affects the influence of their power.

From the perspective of management, we treat the teacher as manager, while the students are the managed, there should also exist diverse ways that use two vectors as axes in the teaching strategy. In work-centered mode, much more attention should pay to the accomplishment of teaching objectives during the teaching process, while in personal relationshipcentered mode; much more attention should pay to the individual need of students. The individual need of students can be said to pursue lowering restricts, which can be easily concluded from their cheering during recess hours.

Being leader, teacher has the task of imparting knowledge to students, and developing their ability. Especially the task of imparting knowledge is limited by the quantity of knowledge; teacher has to finish the task prescribed by syllabus. However, the ability factor can develop in the "freedom" students required, can develop in the process of imparting knowledge (when teachers restrict students' freedom). Therefore, there will have certain contradictions inevitably when pursuing highefficiency teaching method and high-satisfaction teaching method. At present, quality education try to find out the best cut-in point between two different kinds of teaching method. If teacher can find out one teaching strategy that will maximize the "freedom" space of students, maximize the knowledge students can master and their ability, they will undoubtedly gain students' respect and affection.

\section{E. Factors about students}

The influence of teacher's power is not only by teachers themselves, but also by student. The factors are as follows:

\section{1) The cohesion of students}

The so called "students force", is to express the situation that students has to protect, or present themselves, or even expand their power when in social system of teaching. Students should first have a certain understanding of their own power, but also learn how to use their power. The standard of students force is the cohesiveness of their group. The influence of teacher's power will certainly be restricted by the managedstudents' group force.

Student group cohesion strong, all students stand together, each student will get their pioneer's strong support, the teacher has a lot of strength; otherwise, if the student group cohesion is very small, students "in a state of disharmony", group The staff will get weak support, the teacher is sure that the power is very small. If the student community has inherent cohesion, all the students stand together, each student will be the support of their pioneers, then they will have a great influence on the teacher, if the student group internal cohesion is very small, students "in a state of disharmony", the team members will be weak support, the teacher is certainly very little influence.

\section{2) Value preference of students}

If students have strong inherent cohesiveness, and are consistent with teachers in their exercising power, then the influence of teacher's power will be promoted, otherwise, the influence of teacher's power will be weaken. To guarantee that the class teaching activity can start successfully, teachers are given the teaching power, however, when teachers do not understand and abuse their power, real authority will not come into being, while unhealthy interactions between teachers and students will emerge and will do harm to teaching and the development of students. When a student does not agree or resist the power of the teacher in his personal emotion, the teacher will have some negative effects on the use of power.

The influence of teacher's power is restricted by many factors, such as the knowledge storage, personality, and reward and punish method, teaching strategy, the cohesion of students and value preference of the peer and so forth. Besides, according to the development of society, "with the advent of learning-society and advanced educational background of students' parents, the status of teacher will be lowered relatively, the feelings of loss of authority will rise impulsively. In the future society, the status and power of students will be improved, and the relative power of teachers will be weakened, which is an inevitable trend. This is also our consensus on teacher power [5].

\section{SUMMARY}

In teaching method, teachers should change their authoritarian teaching method into democratic one. In class, instead of judging students in one single standard, teachers should try their best to provide time and opportunity for students to show their talents.

For teachers, their work is in the affirmative. In class activities, it is such task orientation makes the relations between teachers and students much more authoritative. Besides, characteristics such as the role of teachers and students, their age, self-conceptions and life experiences makes teacher in the dominant position, and ensure that the knowledge is passed on to students(at low position in knowledge) from teachers (at the top position in knowledge). Effective class teaching needs certain authority. The efforts try to cancel authority of teachers is in vain, and will undermine the effectiveness. However, between teachers and students, we need to find out the best cut-in point between power controlling and equal cooperation. To find out cooperation and equality between teachers and students (mainly means equality from aspect of personality), is not to eliminate the authority of teachers, but to make class teaching much more effective.

\section{REFERENCE}

[1] Li Lanqing, Li Lanqing's Opinion on Quality Education[J], Reference For Quality Education,2004: (4) : p.5.

[2] Xiao Chuan, The Professional Maturity of Teachers and Its Methods [J] Experiment Work Communication, 2003: (4) : p.34-35

[3] Ren Changsong, Reflections and Reconstructions of Curriculum-What Kind of Curriculum Concept Do We Need [M] Beijing: Peking University Press, 2002, p.13.

[4] Gu Mingyuan, Meng Fanhua, New Ideas in International Education [M] Haikou: Hainan Publishing House, 2001,p.189.

[5] Sukkomlinsky, One Hundred Suggestions For Teachers [M] (Dan Lin Trans.) Beijing: People's Education Press, 1986,p.347. 